\title{
Diversity and contested social identities in multilingual and multicultural contexts of the University of the Western Cape, South Africa
}

\author{
Felix Banda and Amiena Peck
}

\begin{abstract}
We draw on Rampton's Crossing: Language and Ethnicity Among Adolescents (2014. 2nd ed. New York: Routledge) notion of 'crossing' to explore contestations in ethnolinguistic, cultural and racial affiliations at the University of the Western Cape (UWC), a university built for 'Coloureds' in apartheid South Africa, but which rebelled by admitting students of all races and ethnic backgrounds. Using interviews and observation data, we show contestations around Xhosa and Afrikaans as languages for black and coloured solidarity, respectively. We argue that the multilingual and multicultural contexts in place entail that social legitimacy is not achieved through fixed linguistics forms, bounded ethnolinguistic categories and predetermined racial characteristics but in negotiated in-group and outgroup codes all of which are part of the students' repertoire. We conclude that diversity is a function of discourses of convergence and divergence as social practice, which give the institution its unique character. The contestations and contradictions thus reflect the democratic conditions on which discourses of diversity are produced and consumed by the multiple socio-cultural range of student populace.
\end{abstract}

\section{The 'bushie' milieu of UWC}

The main aim is to explore discourses of identity and diversity among students at UWC, an institution that went against the apartheid regime to accept students from all ethnic ${ }^{1}$ groups nearly at its very inception (Lalu 2012; Antia 2014; Mafofo and Banda 2014). The article is divided into five sections: the first section gives a historical background to UWC; the second and third sections provide the theoretical framework and methodology respectively; the fourth section is dedicated to analysis of observation data and narratives from students' interviews at various sites on UWC campus, and the last section summarises and concludes the paper.

Saliently, discourses of racism and discrimination, especially with regard to higher education, did not start with the establishment of apartheid in 1948 as segregation of various sorts can be traced to long before 1948 when the National Party came to power (UWC Publications [UWC] 2001). Contrasting UWC with its institutional neighbours, specifically the University of Cape Town (UCT) and Stellenbosch University may be helpful in illuminating the current demographic profile of the university, which has led to it being chosen as a multiplex research site. UCT was founded in 1829 and initially 
established as the South African college catering largely for white English-speaking people. It was first established as a college for boys and later evolved to UCT in 1918. Stellenbosch University was first established as Victoria College in 1865 and was changed to its current name in 1918. It was opened as a result of the white Afrikaner elites' disenchantment with the English, and who for nationalist reasons wanted an Afrikaans university (Gerhart 1978).

UWC was created for coloureds to offer low-level clerical and support labour to whites (Cooper and Subotsky 2001; Bunting 2006). 'Coloured' is a mixed group whose racial background included European, Malay, Griqua and other Khoisan descendants and imported slaves from other parts of Africa (McCormick 2000). The term 'coloured' is contested and we use it guardedly in this case to refer to the group referred as such during apartheid era.

Coupled with a severely restricted curriculum, the funding model for UWC was such that those that graduated from it would remain subservient to white dictatorship rule (see Wolpe 1995; Bunting 2006; Lalu and Murray 2012). The apartheid government tried to ensure maintenance of the apartheid agenda by employing academic staff members from the historically white Afrikaans-medium universities. As Bunting $(2006,45)$ argues such academics tended to readily acquiesce to 'an academic agenda with a strong training focus and, in particular, a focus which placed little emphasis on the production of new knowledge'. Thus, UWC's origins 'defined by the ideological framework of Verwoerdian apartheid, guaranteed its failure as an acceptable place of higher learning' (UWC 1973, 4) as its academic agenda was not geared towards research and production of knowledge. Built in the middle of nowhere, that is, in the 'bush' of the Cape Flats, where the apartheid regime had relocated non-whites from areas they had now designated white only, UWC quickly became known by the then derogatory appellation of 'bush college' - indexing its inappropriate placement. The indifference of the apartheid regime to its own creation could be seen in 'the architecture of the ... campus [which] reflected something of the drabness of the Cape Flats dwellings. There was no redeeming feature to offset the origins and the unattractive physical setting of UWC' (UWC 1973, 14). UWC was designed as such and became known as a second-rate university in comparison with its neighbouring English (University of Cape Town) and Afrikaans (Stellenbosch University) medium universities, with 'students seem[ing] on the whole to attend 'Bush' under protest' (UWC 2001, 6).

However, according to Lalu (2012) even as the apartheid regime was trying to institute a race-based 'Coloured' university, UWC rebelled and by the 1970s accepted any student, whether black, coloured, Indian or white. In addition, UWC jettisoned the apartheid government's academic programme and embarked on 'a massive overhaul of the pedagogic and research orientation of the university, directed at opposition to the state' (Lalu 2012, 107). It started disassembling the ideological foundations of the race-based institutions of higher learning even as they were being put into place. This put it in direct hostility with the apartheid regime. To the chagrin of the apartheid regime, UWC became the epicentre of anti-apartheid demonstrations right from its inception, and challenged 
the imposed monocultural coloured identity (cf. Antia 2014). In 1982 UWC formally rejected the founding apartheid ideology through its new mission statement; and in 1987 in his inaugural lecture as Vice Chancellor at UWC, Jakes Gerwel declared the institution as 'the intellectual home of the left' (Lalu 2012, 106). In the address, Gerwel repudiated the apartheid principles of separate and racialised education thus:

Universities and education generally, reproduce the social order, but it can, alternatively, educate towards and for a changed society. And I cannot in conscience, in truth, educate, or lead education, towards the reproduction and maintenance of social order which is undemocratic, discriminatory, exploitative and repressive and stands universally recognised as such. (Lalu 2012, 106)

This pronouncement was culmination of about 20 years of 'student protests and disavowal of the racial precedents and rationale for the establishment of UWC' (Lalu 2012, 106).

A recent home-grown UWC book entitled 'Becoming UWC: reflections, pathways and unmaking apartheid's legacy' (Lalu and Murray 2012) provides a refreshing new account of the university's 50 years of institutional existence; from a 'bush college' to one of the top academic institutions in South Africa. Ironically, contemporary UWC has appropriated some of the former negative labels of UWC to create a contemporary brand of UWC as 'udubs' and 'bushie' on sweatshirts and other merchandise at the on-campus branding store and during student recruitment campaigns (Mafofo and Banda 2014). The growth of the university is also reflected in the student demographics and size, and the number of new high-tech buildings and research facilities that are mushrooming around UWC (Lalu and Murray 2012; Antia 2014). It is against the background of UWC built on the apartheid ideology of exclusive living for different racial/linguistic groups, but which rebelled to embrace linguistic, cultural and racial inclusivity and diversity, that the paper finds its motivation. The 'diversity' of the student make-up from the 2012 (year of initial research) enrolment figures was Coloured (46.2\%), African (42.4\%), Indian (5.3\%), White (4.7\%) and Other (1.1\%). Provisional data of students' demographics in 2015 show an increase in white students (5.5\%) coupled with a decrease in Indian students (4.7\%), with the other groups remaining largely stable (Coloured, $46.1 \%$, African, $42.5 \%$ and Other (1\%). The 2012 and 2015 enrolment figures, respectively, suggest that $62 \%$ and $61 \%$ of those who self-identified as 'White' indicated that English was their 'home language' and 38\% and $37 \%$ indicated Afrikaans; while $66 \%$ and $67 \%$ of those who self-identified as 'African' indicated Xhosa as their 'home language'. The rest who self-identified as 'African' indicated Sesotho, siSwati, Xitsonga, Setswana, Tshivenda, isiZulu, isiNdebele or 'other' as their 'home language'. For the 'Coloured' group, the 2012 and 2015 respective enrolment figures are as follows: $28 \%$ and $26 \%$ ('Afrikaans home language') and $71 \%$ and $73 \%$ ('English home language'). This monoglot characterisation of the student population does not tally with sociolinguistic data, which suggests that the majority of South Africans speak at least two languages with varying degrees of proficiency in the languages concerned (see Mesthrie 2002; Stroud and Kerfoot 2013; Antia 2014). 


\section{To cross or not to cross: The politics of language and identity}

Our interest is in the changing dynamics in the linguistic performance of identities in the multicultural contexts of UWC in relation to Rampton's (2014) notion of 'crossing' which is defined as 'switching into languages that are not generally thought to belong to you. This kind of switching, in which there is a distinct sense of movement across social or ethnic boundaries, raises issues of social legitimacy that participants need to negotiate' (Rampton 2014, 276). In extending the notion, we want to add that the multilingual and multicultural contexts in which most UWC students are brought up have enabled them to have as part of their cultural capital two or more languages, so that movement between social and ethnic boundaries is the norm rather than the exception. Related notions of 'passing' and 'refusal' as defined below thus become important in accounting for embedded social identities in students' discursive practices as they deploy their extended linguistic heritage. Our interest is in why students, for example, may choose to 'pass' or 'refuse' a given social identity in different contexts. "Passing" is where, in order to avoid all the talk that draws attention to their use of an out-group code, people pretend that the out-group code is actually part of their own inheritance' (Rampton 2014, 276).

The application of these notions can be extended to race. Kamwangamalu $(2001,76)$ remarks that in South Africa during apartheid some blacks who could demonstrate fluency in Afrikaans could 'pass' for coloureds and thus 'have access to the privileges and advantages that were then reserved for coloureds'. 'Refusal' is described as being on the other extreme of 'passing' as a way of 'avoiding the experience of anomaly that crossing entails' (Rampton 2014, 277). 'Refusal' shall refer to an individual spurning in-group codes that would associate them with a particular in-group or ethnic group. However, given South Africa's apartheid history, which included forcing people into perceived ethnic groups, it is conceivable that some students will deliberately 'refuse' to be associated with such groupings to avoid the negative baggage associated with for example the Afrikaans heritage in which the language is associated with the divisiveness and atrocities of the past.

\section{Poststructuralist discourse analysis}

We treat identities as 'multidimensional, contingent and subject to negotiation' (Pavlenko and Black-ledge 2004, 95) and view identities as performed through language and other semiotic resources by an individual or group in social interactions 'to self-name, to selfcharacterize, and to claim social spaces and social prerogatives' (Pavlenko and Blackledge 2004, 19). Identities are thus not fixed. In interactions identities may be contested or maintained on account of cultural, socio-political and economic contexts and the 'local and global relations of power' (Pavlenko and Blackledge 2004, 15). We thus take the view that identities are in a state of flux and should not be determined a priori but as a consequence of interactions of self and significant others in different communicative contexts.

In this paper we use the poststructuralist discourse analysis approach to analyse the generated narratives supplied by informants during interviews and observations of interactions. We find the approach suitable as it frames identities as negotiable 'at the 
interstices of multiple axes, such as age, race class, ethnicity, gender, generation, sexual orientation, geopolitical locale, institutional affiliation and social status' (Pavlenko and Blackledge 2004, 16). We are also mindful of Davies and Harré's (1990) identity positioning theory, whereby 'individuals may be positioned by dominant groups in ways they did not choose, in these situations, individuals or groups may seek to challenge, resist, or transform accepted identity categories to allow for greater identity options' (Pavlenko and Blackledge 2004, 15). During interviews and observations, and analysis of narratives, these variables and notions linked to identity negotiation will be critical in interpreting our data, and engendering a comprehensive appreciation of the sociolinguistic conditions amenable to 'passing', 'refusal' or 'crossing'.

The interviewing process spanned a one-year fieldwork period in 2012, with each interview lasting approximately one hour per group. Focus group interviews were undertaken first and thereafter one-on-one follow-up interviews were conducted to gain better understanding of topics raised by the focus groups. Additional enrolment and demographic statistics, and observation and interview data were collected in 2015.

To allow for an exploration of consistency in 'self' identity or identities emergent from interviews, the initial sampling procedure included 'self-identification' by participants who were asked to claim 'ethnic' identities. In several cases, informants refused to identify themselves with a particular ethnic group. In total 28 key informant interviews (KIIS) and eleven focus group discussions (FGDs) were conducted. Focus groups are a rich base from which to discover differing perspectives and ideological inclinations towards assumed 'self' and 'other' within and across ethnic groups. At the same time focus groups were useful to explore 'crossing' and 'refusal' as the discussion data allowed us to determine the contestations and contradictions between self-identified 'identities' and linguistically performed identities. All interviews were conducted in English by a female 'coloured' Master's student as all the interviewees chose to respond in English even though interpretation services into Afrikaans and Xhosa (the three official languages of the Western Cape Province) were available. All interview sessions were audio-recorded with signed permission of the participants. Interviews were transcribed and treated as the primary source of data. In addition, some students were observed in their 'natural' group setting during leisure time adjacent to the main library (largely perceived as a space for Indian students), the student centre (often the space for coloured and African/black/Xhosa groups) and the local drinking spot known as The Barn (largely considered a space for coloured and African/black/Xhosa groups). Importantly, assumptions posited here about place and student demographics were based on the researchers' prior knowledge of the UWC campus and should not be seen as, in any way, indicative of a hard and fast rule of students, place and race/culture. In line with poststructuralist discourse analysis approaches (Pavlenko and Blackledge 2004), specific themes emergent from observations and narratives of identity are analysed in this paper.

\section{'Refusal and crossing' ethnolinguistic and racial boundaries}

As is still commonplace in South Africa today, UWC often requires students to self-identify as black, African, coloured, Indian, white, Asian or other on official documentation. 
For a start, the neat 'packages' of race and language as definitive markers of ethnicity and points of socio-cultural solidarity do not always come out as orderly as implied and suggested in official university documents. If anything, racialised labels such as African, black, coloured, white and those relating to fixed enthnolinguistic entities such as English, Xhosa, Tsonga and Afrikaans are contested. Students carve out different affiliations and identity 'mixes' for themselves. Below is an extract which highlights this point and looks at how the 'fixed' distinctions of a person being either 'black', 'Xhosa', 'coloured' or 'African' are questioned.

Participant 1: There's just Xhosas and coloureds

Participant 2: No, it's just blacks and coloureds

Participant 1: Just blacks and coloureds, but there's MOSTLY XHOSAS! [All caps denotes emphasis]

It becomes clear from the discussion that the labels 'black', 'coloured' and 'Xhosa' carry different social meanings in different communicative contexts. Participant 1 sees the student populace as made of Xhosa and coloured students which is in contrast with Participant 2 who characterizes the groups as blacks and coloureds. The two participants had initially self-identified to the interviewer as 'Tsonga'. What is interesting is how the informants reposition themselves and others' identities in the discussion at every turn. Participant 1 narrates his experience with Xhosa students:

They just start speaking Xhosa to you and I'm like 'I don't understand what you are saying' and they like 'Oh, what language do you speak?' and I'm like 'Tsonga', and they like 'What?' Tsonga? Where are you from?' Limpopo. 'Oh, where is that?' And I'm like 'What do you mean where is that' and I was like actually surprised that they were asking me where Limpopo is, what Tsonga is.

The informant claims to be a native Tsonga speaker from Limpopo Province in the Northern part of South Africa. Although he speaks Xhosa fluently, he 'refuses' to affiliate to the language and its speakers ostensibly because they do not know his first language or where Limpopo Province is. He is particularly irritated that there is an expectation that all blacks should be able to speak Xhosa or should strive to 'pass' to Xhosa affiliation. Evidently, some black students 'refuse' such affiliation even where it is readily offered. It also seems the case that he is 'refusing' to be positioned by others as Xhosa (Davies and Harré 1990), an affiliation he is willing to negotiate and which he assumes in contexts he uses the language. However, we later learn that 'refusal' to affiliate to Xhosa may have consequences. Consider the following comment from a self-identified Tswana student originally from Pretoria, Gauteng Province in South Africa:

If they ask you something in Xhosa and you say I don't understand that language, they just turn and go. They don't even try to ask in English they just turn and go and leave. 
Like other people from the urbanised Pretoria and Johannesburg Townships, this student is likely to have learnt how to speak Xhosa and related languages in the Nguni family such as Zulu in addition to Tswana and English (Finlayson and Slabbert 1997). The 'refusal' by the Tswana student to 'pass' as Xhosa is taken as a snub by some Xhosa speaking students who retaliate by walking away and 'refusing' to 'pass' as English.

Whereas some students at UWC readily accept English as the lingua franca, others 'refuse' to use English outside the classroom. Another self-identified Tswana informant from Botswana narrates her experience with a shop assistant at the dining hall (DH) at UWC:

I've actually got some attitude from the other lady who works at the DH because I asked for bread in English. They say it in Xhosa. I said 'Excuse me, can I have a loaf of brown bread?' She responded in Xhosa.

Interestingly, English is the official language of education and business at UWC and is also the lingua franca (Antia 2014). But the use of English by the informant irritates the shop assistant who then responds in Xhosa. The informant takes the use of Xhosa as an exercise in 'othering' (Pavlenko and Blackledge 2004) but resorts to the same vice by distancing herself from this ethnic performance of solidarity by the shopkeeper through the expression 'they say it in Xhosa'. When asked if the student has now changed the way she speaks to the lady at the $\mathrm{DH}$, her response was as follows:

No, I still ask the same way. SORRY, she should get used to it. I know how to say it in Xhosa, but I can't cheat myself out of who I am because I want to get accepted. I speak in English whether you understand it or not.

The informant like the other respondents appear to have a single and fixed notion of identity, and thus she feels that speaking Xhosa would imply that she was not being true to her identity. The informant deliberately chooses not to speak Xhosa and makes the connection between speaking Xhosa and being accepted by that ethnolinguistic group. Here, we see the informant's 'refusal' to exercise an aspect of Xhosa identity affiliation. Secondly, the informant adopts a similar attitude as the Xhosa speaker that she has encountered. The informant is willing to speak a language that may potentially not be spoken readily by the next person. Her apparent unwillingness to be associated with Xhosa is met by the other interactant's 'refusal' to be affiliated to English. However, though both 'refuse' to 'cross', they paradoxically understand each other perfectly: with one using Xhosa and the other, English. This linguistic swordplay can be understood in relation to Giles, Coupland, and Coupland's (1991) convergent and divergent behaviours. As the student chooses to deliberately speak a different language to the one expected from her, we see that she undertakes a divergent standpoint. Essentially, the students display signs of deliberate disassociation which can be viewed as a move away from solidarity with the Xhosa identity by one student, and from English by the other student. Evidently, the Tswana student could have very easily 'pass' for a Xhosa speaker as she speaks the language fluently. The informant not only 'refuses' to 'cross', but also opts to use English to intentionally signal that she does not belong to that ethnolinguistic group. She chose to 
use English as the lingua franca and language of instruction at UWC, but which the other speaker in turn 'refused' to acknowledge. This brings to the fore Rampton's (2014, 277) statement that: 'Where there is a common lingua franca, this (refusal to cross) may present no difficulties'. The two are able to communicate effectively using two languages at cross purpose. However as we see in this particular 'altercation', a lingua franca does not always offer a ready solution to resolve attitudinally charged ethnolinguistic-related tensions. In this situation, the affordances provided by social expectations of interlocutors in the communicative contexts are critical factors determining 'refusal' or 'crossing' even in contexts where there is a lingua franca. The shop assistant believes Xhosa is the lingua franca for 'black' people, which is contrary to the Tswana student's expectations. The latter believes English is the lingua franca and that 'crossing' to Xhosa would mean being assimilated and losing her own Tswana heritage. Ironically, it does not occur to the Tswana student that the Xhosa speaker does not want to lose her Xhosa heritage by using English. Other explanations are also possible.

A student who grew up in the Northern Cape speaking Tswana, Afrikaans and English gives further insights into 'refusal' even where one has the linguistic and cultural capital to 'cross' by referring to what she termed the 'democratisation' of UWC's multicultural interactional spaces. She readily 'crosses' to Xhosa when interacting with her many friends from Xhosa speaking background as 'they do not look at me' in a strange way when 'my Xhosa "clicks" do not sound right'. She particularly resents being stereotyped in apartheid-style mono-ethnic discourse:

I usually refuse to speak Xhosa when I feel I'm being stereotyped like during apartheid, that because I'm black then I must speak Xhosa 'properly'.

For this respondent, the 'refusal' to 'cross' extends to Afrikaans, one of the three languages spoken in her home. Her contention is that she mostly speaks English to her coloured friends so as not alienate them due to the 'white' accented Afrikaans she speaks, which is somewhat different from Kaapse Afrikaans spoken by so-called coloured people in the Western Cape.

Several self-identified Xhosa informants indicated that some ethnolingustic Xhosa students 'pretend' not to understand the language just because they were born in the Western Cape Province, or went to former coloured or white only schools, where interaction was in Afrikaans and/or English (see Bangeni and Kapp 2007 for similar view relating to black students at UCT). Similarly the Xhosa student who worked in the DH and apparently perceived the interviewee as a Xhosa speaker may have understood the situation as such that the informant simply did not (want to) speak their shared language. Clearly, 'crossing' is not assured and is not unproblematic in situations where there are lingua francas or exchangeable ethnolinguistic and cultural capital, as ideologies and attitudinal factors mediate the meanings interlocutors attach to language choices, and which identity options they are willing to affiliate to or reject. 
It is clear from the foregoing that notions of 'crossing', 'passing' and 'refusal' in a way function to show the porousness of ethnolinguistic, and even racial boundaries as discussed below. In the extract below we give an example of a Tswana informant from Botswana that is intriguingly both mistaken for being coloured ('mixed race') as well as 'Xhosa' (African black).

They get confused, they don't know if I'm coloured or Xhosa. When [coloureds] address me they speak Afrikaans and I tell them 'man I don't understand Afrikaans'. They look at me with confusion. I don't speak Afrikaans, 'speak in English we will talk'. Now the Xhosa people I always tell them I don't understand what you saying, 'speak in English we will talk.'

His physical features, especially complexion and hair texture make him 'pass' as a black (Xhosa) or coloured in the eyes of these contesting groups. However, his attitude to both ethnic groups is exactly the same, which is that he is willing to associate with them but in English. Evidently, had he the linguistic capital, he could 'cross' into Xhosa or coloured affiliations.

\section{Contesting the Afrikaans coloured identity}

Below is an excerpt of an interview which resulted in the baring of the "English coloured' who'refuses' to be associated with the 'Afrikaans coloured'. She responds to a question on whether she interacts with other ethnic groups thus:

Participant: This is gonna sound very rude. I do have lot of South African black friends, but not Afrikaans coloureds

Interviewer: But why not?

Participant: You see you're English right? Where do you come from or where did you grow up?

Interviewer: Athlone

Participant: So you have a lot of English friends, right? You don't have a lot of Afrikaans friends? WOULD YOU MIX WITH AFRIKAANS PEOPLE?

Interviewer: I would

Participant: Would you make them your common friends? DON’T LIE NOW!

Interviewer: Yes. You don't believe me?

Participant: No, I don't, so my point is, here you are, you coloured and they coloured. But you are English and they are Afrikaans

It is important to reiterate that majority of students come from bi-multilingual homes (Stroud and Kerfoot 2013). The interviewee's parents speak Afrikaans and English to her at home, but she decided only to speak English and seeks her friends mostly from English-speaking 'coloureds' and (English-speaking) blacks (Africans). She challenges the veracity of the interviewer's interest in Afrikaans coloureds. She does so to prove that there is a difference between coloureds which is language-based. She tries to draw the interviewer into her perspective that English-speaking and Afrikaans-speaking coloured do not socialise and that they are mutually exclusive. There is no doubt that she speaks 
and understands Afrikaans, which she passed at senior school level which enabled her entry to university.

It is also interesting that the interviewee says she is an 'English coloured' but affiliates with the racially and historically different black friends, with whom she associates through a shared language, English. She wants to have nothing to do with Afrikaans-speaking coloureds with whom she shares racial and historical heritage. What the extract demonstrates is that racial and shared ethnolinguistic heritage are not sufficient factors determining linguistic and racial affiliation in discourse practice.

\section{Peeking into 'Little Bombay'}

What follows is a glance into the dynamics of an assumed Indian space known informally as Little Bombay (LB). Informants told us it is a place where students that self-identify as Indian hang out. Although students have been seen around this spot for years, very little has been previously understood of the groups that patronise LB.

If you don't know anybody, don't go sit there because they will look at you like you're from out of space.

A student who described himself as an Indian first year at UWC, made this comment of LB. This comment implies that being Indian is not a sufficient characteristic to be accepted as belonging to the group that claims ownership of the space. What we see is that LB is patronised by a close-knit network (Milroy 1987) of a particular 'type' of Indian. During the research we found out that this network is not open to all Indians as commonly thought by other informants, but rather only a select group of them. Both third year informants (when recounting their experiences in first year) and the first year informants agreed that LB is 'exclusive' with those Indians that hang out there simply ignoring you if they do not know you. Language and ethnicity are not distinctive markers in LB, as most of the Indian students claimed to be Indian and speak English, with Urdu or Cockney being spoken by only a few and then largely only in jest.

Evidently, in terms of spatial ownership to LB, there appears to be a regular cyclical turnover that sustains this space as 'Indian'. The most stable group is the third year as they can always claim the other students found them there. But as they graduate, the previous second years take over control. Social legitimacy and 'crossing' into the dominant Indian social network is determined by length of stay in the space rather than shared ethnolinguistic, racial and cultural heritage.

Another interesting feature was the discovery of an apparent contradiction in which the Indian informants 'crossed' and at the time 'refused' coloured identity options. Interviewees would start English and later drift to Kaapse Afrikaans or Kaapse in short (Afrikaans as spoken by coloureds in the Western Cape) as seen in the following extract:

Interviewer: Why do you say your parents won't approve of interracial relationships? Participant 1: Because $=$ 
Participant 2: =Jou Pa sal jou vrek maak! (laughs) 'Your father will kill you!'

Participant 1: My father just won't allow it.

$=$ indicates overlap

Participant 2 interjects with a Kaapse phrase. 'Jou Pa sal jou vrek maak!" literally translated into 'Your father will kill you!' This could have been said in Standard Afrikaans which would have been 'Jou Pa sal jou dood maak!'. What we see here is that the informant not only opted for a different language (Afrikaans) but also the variety of that language known as Kaapse used by coloureds in the Western Cape (McCormick 2000). In practice she has 'crossed' into coloured identity affiliation through the use of Kaapse in order to 'refuse' that same identity affiliation. This at face value looks like a contradiction, but it is not, as social history indicates that Kaapse is integral to the bilingual heritage of those that self-identify as Indian (McCormick 2000). Drawing on her linguistic heritage the speaker is aware the right register and finely tuned meaning can only be achieved, not using English or standard Afrikaans, but through Kaapse. Both 'vrek' and 'dood' mean 'to kill' in English. However, in Afrikaans, the difference can be understood in terms of register. Had the informant opted to use 'dood' instead of 'vrek' she may have signalled a more formal variety and/or 'white' identity. The friend then softens what is said by changing 'will kill you' with 'just won't allow it'. Here we see that the Kaapse statement held a lot more meaning and delivered more affect as it talks of 'killing' while the other participant statement talks about 'permission' and how her father wont 'allow it'.

Kaapse was quite prevalent during interviews with other Indian students, as shown below:

When I have lis to make gaai I speak a little bit of Cockney in between.

Literally translated, the above statement can be understood as: 'When I feel like being funny I speak a little bit of Cockney in between'. The words 'lis' and 'gaai' are being used in the exact way a Cape coloured on the Cape Flats would use them. This is also the kind of English/Kaapse one finds in the Daily Voice, which targets Cape Flats readers (Matthews 2010). What is interesting about this statement is that the informant talks about speaking in Cockney for comedic affect whilst simultaneously opting for the use of Kaapse to illustrate her meaning. This can also be seen below when another Indian informant talks about her mother gossiping in Hindi but using a word from Kaapse:

When my mommy skinner in Hindi then we know what she's saying because we understand.

Skinner is informal Kaapse word used on the Cape Flats by coloureds and means 'gossip'. Kaapse is also shown through lack of indicating for number (singular form of verb is often used in all cases) and generally using English words in a different way (McCormick 2000) as shown below. 
I think our mindsets has changed because before we would never ever sit on the wall by the library. But now it's like totally changed I mean, in the morning when I come to campus the place I go to is there and it's not like 'oh you going to Bombay' or 'you lamming in Bombay'.

The word 'lamming' is relatively old coloured slang and means 'hanging around' or 'chilling' in a specific spot. In this instance it was given a derogatory connotation, as if 'lamming' was a bad word meaning 'lazing around'. Clearly, there is a great deal of interaction between so called Indians and so called coloured as they apparently share the Kaapse language. Yet, the Indian informants in this study unequivocally refused to identify as Afrikaans-speaking or coloured, notwithstanding their declarations of difference, the manner in which the language is performed belies their much more layered Kaapse linguistic heritage.

\section{The Chinese at UWC}

Across the board amongst the informants interviewed, there was an overwhelming positive attitude towards Chinese students at UWC. This is quite interesting, as most of the informants had no real contact with the Chinese students. What has become evident from interviewing the Chinese informants themselves was that there was a definite goal for studying at UWC. Those we interviewed came to increase their proficiency in English, and their place of study was extremely important and based on a number of factors. In a sense, for these Chinese students, UWC was the only place for them to attend. The reason given by one informant suggests a process of elimination with UWC selected as the tertiary institution of choice:

Cape Town just got the Pentech and the maybe the Cape Tech, UCT, Stellenbosch and UWC. Now Stellenbosch you study the Afrikaans, I cannot bear, and UCT they [need] high tuition [fees] so I can't go there and the Pentech is only a college but I need a University, so I choose to come to [UWC].

However, even though the goal for these students is to increase their knowledge in English, they often find themselves isolated from other students on campus and in turn ultimately end up speaking to their Chinese colleagues in Chinese. This may occur because some of them lack the self-confidence and belief in using English as shown by a first year Chinese student's comment:

I afraid my English is not good enough to talk another body but sometimes I realize I have to speak, so I try to speak a little.

No doubt this student's self-isolation is counterproductive to her aspirations to improve her English proficiency. The other factor influencing the Chinese students' self-isolation, leading to failure to increase their proficiency, has to do with their close social network with other Chinese students. One coloured informant describes Chinese students as being ' ... unsociable but friendly'. This may seem as a contradiction in terms, but is at the same time a very accurate description of the paradoxical perception of Chinese students at 
UWC. The reason why they may appear to be 'unsociable' lies in the fact that they interact in close-knit social networks. One Chinese informant is aware that her interactions in Chinese networks limit her chances of practicing English:

I study together with the Chinese students. I think it's not good. I think this is an error [to interact] on the campus with the Chinese not with the local people.

Apart from working against her goal to improve her English-speaking competence, this also limits her chances of experiencing the rich cross-cultural currents at UWC.

However, we found there are a good number of Chinese students who interact regularly with local students. A number of Chinese informants said they shared several cultural values with 'blacks', especially the social taboo against discussing topics of a sexual nature in public. Below we describe an interview with a Chinese student who belongs to several coloured social networks. The Chinese informant has appropriated the verbal behaviour of some coloured students at UWC as his own, to express his dismay at social taboo being expressed openly. He 'crosses' and linguistically performs coloured identity options while condemning the verbal behaviour of some coloured students in his social networks:

[Some coloured students] always talking about the woman. The Chinese sex, the Chinese woman. I say 'Hey, what are you talking about? Why you always asking me this question?' always ask me 'Help me, help me, help me to organise a Chinese girl'. I say '[expletive]!' They always talk about the ladies breasts.

The English word 'organise' is a term appropriated by Kaapse to mean the 'arranging' or 'fixing' of somebody for romantic or sexual purposes. The informant expressed disgust and anger towards this issue and the manner in which it is brought about. The ramifications of this type of cultural clashing are deeply rooted and the informant generalises the vulgarity to the rest of South Africa:

If in China somebody come from the overseas, somebody come from another country you give a good manner to them because your topic and your speech does not meant only yourself it means YOUR COUNTRY so when I go back to China somebody ask [about] South Africa, the coloured people very [expletive].

It is noteworthy that this Chinese student actively performs the 'culture of vulgarity' which he associated to coloureds generally. In his case, he is speaking freely to a female coloured interviewer on sexual matters and using the same 'coloured' language he is condemning. The Chinese informant does not flinch in using 'vulgar' language as illustrated further below:

They [coloureds] always talk about the ladies breast and the also and teach me this word 'your ma se [expletive]' [your mother's [expletive]'and I say 'what this mean?' They say 'Go back and ask some people'. 
Why did this Chinese informant feel the need to repeat the speech that even he considered to be rude and inappropriate? One could argue that the 'vulgarity' of this experience and the intense 'uncouthness' associated with these words could only be divulged on expressing the actual words which embody it. Here we see that the informant deliberately chooses to 'cross' to Kaapse for communicative effect. However, rather than distancing himself from Kaapse identity, the fact that the informant opts to repeat the Kaapse phrases in front of a 'coloured' female interviewer makes himself 'cross' into the same identity affiliation he is condemning. It may also be that the participant felt that his point would be more readily understood in Kaapse - the language ostensibly readily understood by the coloured interviewer. The interviews with the Chinese student illustrate another layer in the notion of 'crossing', which is to distance oneself from the other ethnic/racial group through drawing on the linguistic repertoire associated with that particular ethnic group. Paradoxically, the desire to disengage with the other is made possible through affiliating linguistically with the same group.

\section{Summary and conclusion}

It is fairly obvious to determine that although in their verbal responses interviewees portray a mono-ethnolinguistic (identity) affiliation, it is also the case that they are multilingual and able to affiliate to multiple groups. It seems they will speak different languages depending on contexts; especially where they are not being stereotyped or actively coerced to speak a particular language or to adopt a particular ethnolinguistic identity. Specifically the idea that an individual should speak a particular language because s/he looks a certain way is spurned. To this end, snap judgements where a speaker makes a one-to-one relationship between ethnolinguistic identity/race and language, become the ground for 'refusal' to 'cross' or 'pass'. This is important when revisiting the ramifications of instantiations of refusal, particularly as informants in this study reveal that a refusal to cross may be more salient than crossing itself. Put another way, refusal to cross into apartheid 'boxes' and divergence from mollifying an overriding norm positions UWC as fertile grounds for democratic engagement.

The paper also revealed a peculiar form of 'incidental crossing' wherein informants would cross into other groups in moments of amusement or outrage. The Indian informants' skilful use of Kaapse Afrikaans revealed that they could very easily cross into Coloured group even though they consciously (and vehemently) refused to admit to any potential malleability between the two groups. Likewise with the Chinese student who, in his (understandable) anger towards misogynistic comments by coloured men, incidentally crosses into Kaapse Afrikaans, a variety associated with coloured people in the Western Cape Province.

Clearly, English, Xhosa, Afrikaans and other languages at UWC play a somewhat paradoxical role in the formation and contestation of multilingual identities. Firstly, an identity of 'being English' or 'becoming English' is seen as an academic necessity by all students attending UWC (which is plausibly the case at any other English medium university). English plays the powerful role of being a prestigious language which is believed to propel any speaker of the language to upward mobility and subsequent 
success. In a sense one could posit that English forms an identity factor in all students at UWC in some way. However, its role as a lingua franca and identity marker is often contested by other linguistic and identity options available to students. Thus, the perceived role of English as a national and unifying language across diverse groups as indicated in the UWC (1989) document is undermined in the process. We found that students find value - both symbolic and cultural - in languages other than English. The signalling of these linguistic options on the other hand is an entirely different and interesting occurrence altogether. When discussing the identities that these linguistic options entail, one needs to differentiate between whether these identities are being used on an academic or social level or both. In terms of English, it is important to distinguish between its use inside and outside the lecture halls. Whereas inside the classroom it can be said to be uncontested, outside the classroom English is just one of the many linguistic options in the wider linguistic market and is open to contestation. This is in sharp contrast to a longitudinal study on language practices among black students at neighbouring UCT, a previously white only university (Bangeni and Kapp 2007). Bangeni and Kapp's (2007) study suggests that at UCT English is both the language for the classroom and outside class interpersonal interactions. Bangeni and Kapp found that the black students were assimilated into English so that 'students from the [black] township schools spoke of how they could not always remember words in their home languages whilst in the [UCT] university environment' (Bangeni and Kapp 2007, 263). A recent study at UCT corroborates Bangeni and Kapps' findings. Buhle Zuma, a UCT PhD graduate, found that black students have to 'perform whiteness' through middle class private school English accent to be accepted into UCT social networks (Zuma 2013). It would appear that the use of English in social circles is uncontested. An explanation for this could be that UCT was built for English-speaking white students and it appears the tradition of speaking a particular kind of English is being maintained and is also part of its institutional identity. The Rhodes Must Fall protest movement which culminated into the removal of the John Cecile Rhodes statue from the entrance of UCT on 9 April 2015 should be seen as a challenge to UCT's institutionalised British English heritage, which has stood since 1829. Protesters also saw its fall as an attempt at 'decolonisation' and democratisation, which would lead to the transformation of UCT's curriculum, student admissions and academic appointments policy.

Drawing on contestations around social and racial categories such as Xhosa, black and coloured we have shown that 'crossing' and related notion of 'refusal' and 'passing' can be applied to both ethnolinguistic and racial affiliations. We have also shown that achieving social legitimacy is not through fixed linguistics forms, bounded cultural and ethnic categories and predetermined racial characteristics but in the negotiations of the contradictions in mobile in-group and out-group codes which constantly intersect and which are also part of students' linguistic and socio-cultural repertoire and inheritance.

We want to conclude that UWC's historiography and the multilingual and multicultural heritage in place call for a dynamic conceptualisation of the notion of 'crossing' as illustrated in this paper in which ethnic, linguistic and racial boundaries are porous in the 
performativity of social identities. Thus, we also want to conclude that at UWC diversity is embedded in the discourses of inclusion and exclusion that constitute its communicative contexts, which also gives the institution its unique character and identity. The apparent contestations and contradictions therefore provide the material affordances that create democratic conditions on which discourses of diversity are produced and consumed by the multiple socio-cultural range of student populace.

\section{Note}

1. Importantly, participants in this study often use terms such as 'race' and 'ethnicity' interchangeably and the authors do not hold to any particular predetermination of either concept, rather the messiness and mutability of both terms recognized as an inherent flaw in social/human dynamics.

\section{Acknowledgement}

This material is based upon work supported financially by the National Research Foundation. Any opinion, findings and conclusions or recommendations expressed in this material are those of the authors and therefore the NRF does not accept any liability in regard thereto.

\section{Disclosure statement}

No potential conflict of interest was reported by the authors. 


\section{References}

Antia, B. E. 2014. "University Multilingualism: A Critical Narrative from the University of the Western Cape, South Africa." Journal of Multilingual and Multicultural Development 36 (6): 571-586. doi:10.1080/01434632.2014.978870.

Bangeni, B., and R. Kapp. 2007. "Shifting Language Attitudes in a Linguistically Diverse Learning." Journal of Multilingual and Multicultural Development 28 (4): 253269.

Bunting, I. 2006. “The Higher Education Landscape under Apartheid.” In Transformation in Higher Education: Global Pressures and Local Realities, edited by Nico Cloete, Peter Maassen, Richard Fehnel, Teboho Moja, Trish Gibbon, and Helene Perold, 35-52. Amsterdam: Springer.

Cooper, D., and G. Subotsky. 2001. The Skewed Revolution, Trends in South African Higher Education: 1988-1998. Cape Town: University of the Western Cape.

Davies, B., and R. Harré. 1990. "Positioning: The Discursive Production of Selves." Journal for the Theory of Social Behaviour 20 (1): 43-63.

Finlayson, R., and S. Slabbert. 1997. "We Just Mix': Codeswitching in a South African Township.” International Journal of the Sociology of Language 125 (1): 65-98.

Gerhart, G. M. 1978. Black Power in South Africa: The Evolution of Ideology. Berkeley, CA: University of California Press.

Giles, H., J. Coupland, and N. Coupland. 1991. Contexts of Accommodation. Cambridge: Cambridge University Press.

Kamwangamalu, N. M. 2001. "Ethnicity and Language Crossing in Post-Apartheid South Africa.” International Journal of Sociology of Language 152: 75-95.

Lalu, R. 2012. "Constituting Community at the Intellectual Home of the Left." In Becoming UWC: Reflections, Pathways and Unmaking Apartheid's Legacy, edited by R. Lalu and N. Murray, 105-115. Bellville: UWC Centre for Humanities Research.

Lalu, M., and N. Murray, eds. 2012. Becoming UWC: Reflections, Pathways and Unmaking Apartheid's Legacy. Cape Town: UWC Centre for Humanities Research.

Mafofo, L., and F. Banda. 2014. "Accentuating Institutional Brands: A Multimodal Analysis of the Homepages of Selected South African Universities." Southern African Linguistics and Applied Language Studies 32 (3): 417-432.

Matthews, W. 2010. "Multimodality and Negotiation of Cape Flats Identity in Selected Daily Voice Front pages." Unpublished MA thesis, University of the Western Cape, Bellville.

McCormick, K. 2000. Language in Cape Town's District Six. Oxford: Oxford University Press.

Mesthrie, R. 2002. Language in South Africa. Cambridge: Cambridge University Press.

Milroy, L. 1987. Language and Social Networks. 2nd ed. New York: Basil Blackwell Ltd.

Pavlenko, A., and A. Blackledge. 2004. "Introduction: New Theoretical Approaches to the Study of Negotiation of Identities in Multilingual Contexts." In Negotiation of Identities in Multilingual Contexts, edited by A. Pavlenko and A. Blackledge, 1-33. London: Cromwell Press.

Rampton, B. 2014. Crossing: Language and Ethnicity Among Adolescents. 2nd ed. New York: Routledge. 
Stroud, C., and C. Kerfoot. 2013. "Towards Rethinking Multilingualism and Language Policy for Academic Literacies." Linguistics and Education 24 (4): 396-405.

UWC. 1973. The University of the Western Cape in a Changing South Africa. Bellville: UWC.

UWC. 1989. A University in Action. Bellville: UWC.

UWC. 2001. A University in Action. Bellville: UWC.

Wolpe, H. 1995. "The Debate on University Transformation in South Africa; The Case of the Western Cape." Comparative Education 31 (2): 275-292.

Zuma, B. 2013. Talk White and We'll be friends. IOL Lifestyle. (June 10, 2013 01:19pm). Accessed October 27, 2014. http://www.iol.co.za/lifestyle/family/friends/talkwhite-and-we-ll-be-friends-1.1529977\#.VjcotrfhDcs 